\title{
Assessing Anopheles vector species diversity and transmission of malaria in four health districts along the borders of Côte d'Ivoire
}

Firmain N. Yokoly ${ }^{1,2^{*}} \mathbb{D}$, Julien B. Z. Zahoulii, ${ }^{2,3}$, Graham Small ${ }^{4}$, Allassane F. Ouattara ${ }^{1,2}$, Millicent Opoku ${ }^{5,6}$, Dziedzom K. de Souza ${ }^{5}$ and Benjamin G. Koudou ${ }^{1,2}$

\begin{abstract}
Background: Although malaria and Anopheles mosquito vectors are highly prevalent in Côte d'Ivoire, limited data are available to help understand the malaria vector density and transmission dynamics in areas bordering the country. To address this gap, the Anopheles mosquito species diversity, the members of the Anopheles gambiae complex and the transmission of malaria were assessed in four health districts along the borders of Côte d'Ivoire.

Methods: From July 2016 through December 2016 and July 2017 through December 2017, adult Anopheles mosquitoes were collected in four health districts of Côte d'Ivoire (Aboisso, Bloléquin, Odienné and Ouangolodougou) using standardized window exit trap (WET) and pyrethrum knockdown spray collection (PSC) methods. The collected mosquitoes were identified morphologically at species level and the members of the An. gambiae complex were separated using short interspersed nuclear element-based polymerase chain reaction (SINE-PCR). Anopheles gambiae sensu lato (s.l.), Anopheles funestus s.l. and Anopheles nili specimens were analysed for malaria Plasmodium parasite detection using the cytochrome oxidase I gene (COX-I), and malaria prevalence among human population through local Ministry of Health $(\mathrm{MoH})$ statistical yearbooks.
\end{abstract}

Results: A total of 281 female Anopheles were collected in Aboisso, 754 in Bloléquin, 1319 in Odienné and 2443 in Ouangolodougou. Seven Anopheles species were recorded including An. gambiae s.l. (94.8-99.1\%) as the main vector, followed by An. funestus s.l. (0.4-4.3\%) and An. nili (0-0.7\%). Among An. gambiae s.l., Anopheles coluzzii represented the predominant species in Aboisso (89.2\%) and Bloléquin (92.2\%), while An. gambiae sensu stricto (s.s.) was the major species in Odienné (96.0\%) and Ouangolodougou (94.2\%). The Plasmodium sporozoite infection rate in An. gambiae s.l. was highest in Odienné (11.0\%; $n=100)$ followed by Bloléquin $(7.8 \%, n=115)$, Aboisso $(3.1 \% ; n=65)$ and Ouangologoudou (2.5\%; $n=120)$. In An. funestus s.l., Plasmodium falciparum sporozoite infection rate was estimated at $6.2 \%$ $(n=32)$ in Bloléquin, 8.7\% $(n=23)$ in Odienné. No An. funestus s.l. specimens were found infected with P. falciparum sporozoite infection in Ouangolodougou and Aboisso. No P. falciparum sporozoite was detected in An. nili specimens in the four health districts. Among the local human populations, malaria incidence was higher in Odienné (39.7\%; $n=45,376)$ and Bloléquin $(37.6 \% ; n=150,205)$ compared to that in Ouangolodougou $(18.3 \% ; n=131,629)$ and Aboisso (19.7\%; $n=364,585)$.

\footnotetext{
*Correspondence: yokolynd@yahoo.fr

${ }^{1}$ Unité de Formation et de Recherche Sciences de la Nature, Université Nangui Abrogoua, Abidjan, Côte d'Ivoire

Full list of author information is available at the end of the article
}

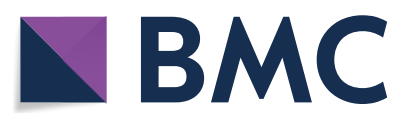

(c) The Author(s) 2021. Open Access This article is licensed under a Creative Commons Attribution 4.0 International License, which permits use, sharing, adaptation, distribution and reproduction in any medium or format, as long as you give appropriate credit to the original author(s) and the source, provide a link to the Creative Commons licence, and indicate if changes were made. The images or other third party material in this article are included in the article's Creative Commons licence, unless indicated otherwise in a credit line to the material. If material is not included in the article's Creative Commons licence and your intended use is not permitted by statutory regulation or exceeds the permitted use, you will need to obtain permission directly from the copyright holder. To view a copy of this licence, visit http://creativecommons.org/licenses/by/4.0/. The Creative Commons Public Domain Dedication waiver (http://creativeco mmons.org/publicdomain/zero/1.0/) applies to the data made available in this article, unless otherwise stated in a credit line to the data. 
Conclusion: Anopheles vector species diversity, abundance and Plasmodium sporozoite infection were high within the health districts along the borders of the country of Côte d'Ivoire, resulting in high malaria transmission among the local populations. Anopheles gambiae s.l. and An. funestus s.l. were found to be highly infected with Plasmodium in the health districts of Bloléquin and Odienné where higher malaria incidence was observed than the other districts. This study provides important information that can be used to guide Côte d'Ivoire National Malaria Control Programme for vector control decision-making, mainly in districts that are at the country borders.

Keywords: Malaria, Plasmodium, Anopheles, Border health district, Côte d'Ivoire

\section{Background}

Malaria remains the deadliest tropical infectious disease, with higher incidences in Africa [1]. In 2018, malaria has caused over 228 million cases and 405,000 deaths worldwide, of which 93\% has occurred in sub-Saharan Africa [1]. In 2019, the overall number of cases increased from 228 to 229 million of malaria cases with 409,000 deaths [2]. In Côte d'Ivoire, malaria is still a major public health challenge and the leading reason for consultations in health services. It is responsible for up to $43 \%$ of morbidity, $11.8 \%$ of mortality, $40 \%$ of school absenteeism, $50 \%$ of loss of agricultural income and $62 \%$ of hospitalizations [3]. According to the world malaria report, the entire Ivorian population is at risk of malaria, with the most vulnerable being children under 5 years of age and pregnant women [4].

Malaria transmission in Africa is very heterogeneous due to eco-climatic variations across the continent [5]. Currently, five species of the Plasmodium parasites have been identified as being responsible for malaria infection in humans [6, 7]. Of these, Plasmodium falciparum remains the most prevalent and most virulent species causing the deadly forms of malaria $[7,8]$. The Plasmodium species responsible for human malaria are mainly transmitted by primary vector species, such as Anopheles gambiae sensu lato (s.l.) [9], Anopheles funestus group and Anopheles nili group [10-12].

In West Africa, two molecular forms have been identified in An. gambiae s.l., formerly known as $\mathrm{M}$ and S. Recently, they have been identified as distinct species belonging to the An. gambiae complex and named Anopheles coluzzii for the $\mathrm{M}$ form and An. gambiae sensu stricto (s.s.) for the $\mathrm{S}$ form [10]. These species display strong anthropophilic host-seeking behaviour and longevity, causing large numbers of malaria cases [13]. Anopheles larvae are aquatic and found in a variety of breeding habitat types in terms of size, permanence, vegetation and water cleanliness [14]. Overall, the larvae of An. gambiae s.l. grow in small, shallow, relatively clean and sunny water reservoirs (puddles of water, stagnant water) $[15,16]$, and is more frequent and rain-dependent. Anopheles coluzzii is associated to permanent breeding sites and those resulting from human activity and prefers urban water collections and adapts quickly to pollution [17, 18]. According to Mourou et al. [19], the breeding habitats of this species are known to increase in number and productivity during the rainy season, but almost disappear during the dry season. Deploying major vector control interventions, such as the scale-up of long-lasting insecticidal nets (LLINs) and indoor residual spraying (IRS), requires detailed understanding of the species composition, distribution and behaviour dynamics of the local vectors to avoid limited impact or intervention failure $[20,21]$.

In Côte d'Ivoire, the malaria vectors An. gambiae s.s. and An. coluzzii are widespread across the country [22, 23], whilst An. funestus s.l. and An. nili act as secondary vectors [24]. Anopheles gambiae s.s. and An. coluzzii are well-adapted to diverse types of breeding sites (e.g., permanent breeding sites or temporary rain pools such as puddles, shallow wells, footprints, or in rice and vegetable fields), which are generally frequent in both rural and urban areas [25]. The country shows considerable bio-climatic variations from the North to the South, leading to the subdivision of the country into different ecological zones [26]. Thus, the South-East of Côte d'Ivoire is marked by coastal inland lagoons [27]. The southern region, especially the South-West, is covered with dense tropical rainforest. The Guinean forest-savannah mosaic belt extends across the middle of the country from the East to the West and the northern part belongs to the Sudanian savannah. All these ecological conditions contribute to the proliferation of many malaria vector species across the country [28]. This contributes to the stability of malaria transmission throughout the year, with peaks during the rainy season [29]. Identifying these vector species and their involvement in malaria transmission in these different ecological zones could provide essential information that could guide the planning and implementation of vector control measures. Furthermore, limited entomological data are available on disease transmission dynamics, particularly in districts along the borders of the country. This study assessed the species diversity of Anopheles mosquito vectors, members of the An. gambiae complex and transmission of malaria in four health districts at the border areas of Côte d'Ivoire. 


\section{Methods}

\section{Study sites}

The study was conducted in the four-health districts of Côte d'Ivoire. The health districts are namely Aboisso $\left(5^{\circ}\right.$ $\left.28^{\prime} \mathrm{N}, 3^{\circ} 12^{\prime} \mathrm{W}\right)$ and Bloléquin $\left(6^{\circ} 34^{\prime} \mathrm{N}, 8^{\circ} 00^{\prime} \mathrm{W}\right)$ Odienné $\left(9^{\circ} 30^{\prime} \mathrm{N}, 7^{\circ} 33^{\prime} \mathrm{W}\right)$ and Ouangolodougou $\left(9^{\circ} 58^{\prime} \mathrm{N}\right.$, $\left.5^{\circ} 09^{\prime} \mathrm{W}\right)$ (Fig. 1).
The district of Aboisso is located in the primary rainforest of Cote d'Ivoire in the south-western border with Ghana. The climate is humid tropical, characterized by abundant rainfall with a mean annual of about $1500 \mathrm{~mm}$ of rain. The average annual temperatures are between 25 and $27{ }^{\circ} \mathrm{C}$. This district covers an area of over $4662 \mathrm{~km}^{2}$ with a population of 307,852 people representing a

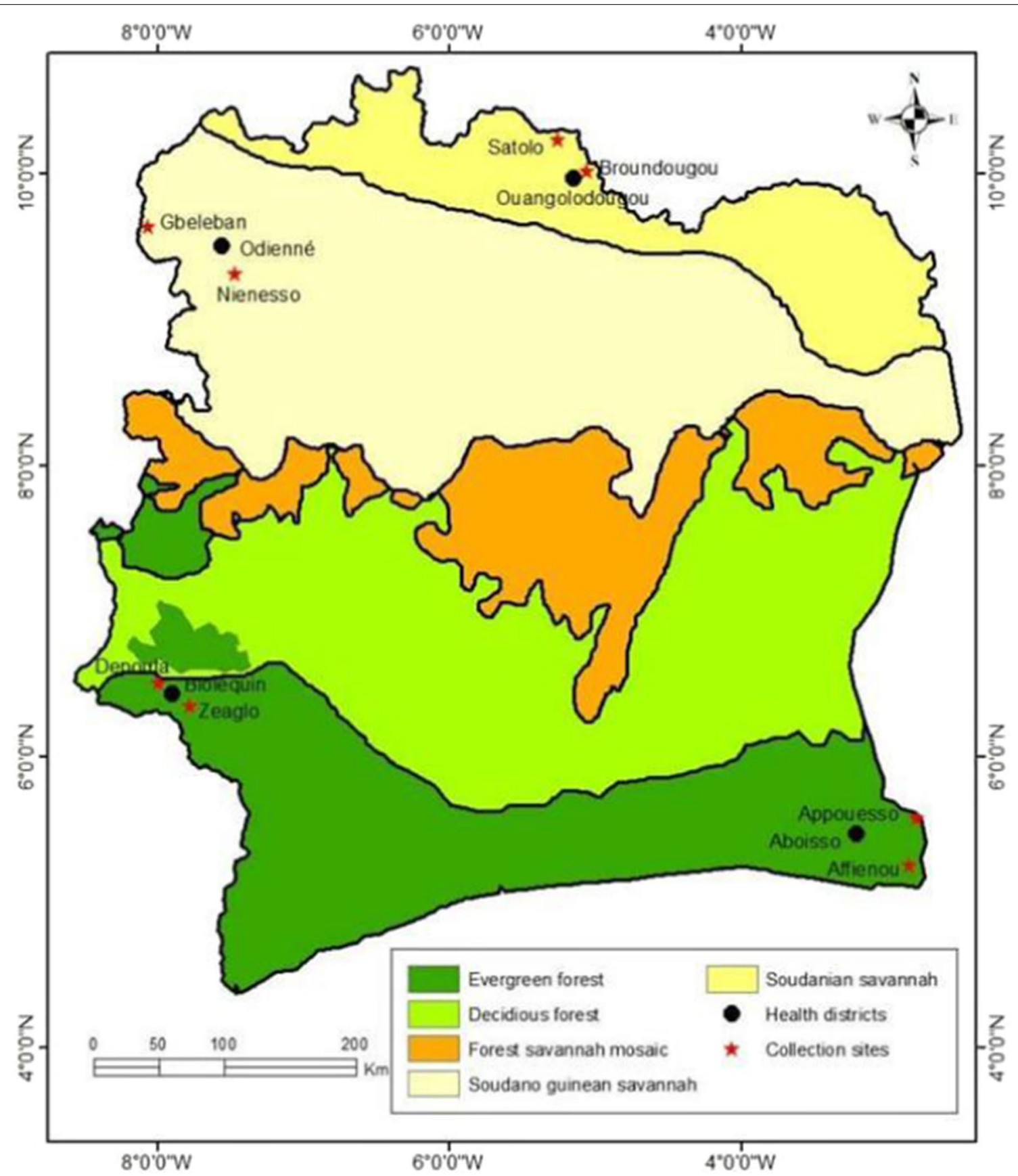

Fig. 1 Map of Côte d'Ivoire showing the study sites in the four health districts (Aboisso, Bloléquin, Odienné and Ouangolodougou) along the borders of Côte d'Ivoire 
density of about 66 inhabitants per $\mathrm{km}^{2}$ [30]. In the district of Aboisso, Anopheles mosquitoes were collected in the villages of Affiénou ( $\left.5^{\circ} 25^{\prime} \mathrm{N} ; 2^{\circ} 56^{\prime} \mathrm{W}\right)$ and Appouesso $\left(5^{\circ} 57^{\prime} \mathrm{N} ; 3^{\circ} 10^{\prime} \mathrm{W}\right)$. Both villages are irrigated by numerous streams and lowlands, and have modern and traditional housing, a health centre, electricity and water supply. Coffee, cocoa, rubber and palm oil are the main cash crops while vegetable, cocoyam and banana are the main food crops in the area.

The district of Bloléquin is situated in the dense forest zone in the West of Côte d'Ivoire at the border with Liberia. The population is about 123,336 inhabitants [30]. The climate is mountainous, with annual average rainfall sometimes exceeding $2000 \mathrm{~mm}$ per year and annual temperatures ranging from 15 to $33{ }^{\circ} \mathrm{C}$. It covers an area of $2962 \mathrm{~km}^{2}$ with a population density of approximately 41 inhabitants per $\mathrm{km}^{2}$. The district is irrigated by important tributaries coming from the Sassandra and Cavally rivers, enabling the establishment of various permanent water bodies, puddles and small dams. The study sites in this district covered the villages of Zéaglo $\left(6^{\circ} 34^{\prime} \mathrm{N}, 7^{\circ} 47^{\prime} \mathrm{W}\right)$ and Dépouta $\left(6^{\circ} 54^{\prime} \mathrm{N}, 7^{\circ} 57^{\prime} \mathrm{W}\right)$. Only Zéaglo has a health centre, electricity, water supply and modern housing. The agricultural activity is mainly based on coffee, cocoa and rubber cultivation. Food crops are dominated by banana, cassava, maize and vegetables, and included flooded lowland rice paddy and rainfed rice cultivation.

The district of Odienné is in the savannah zone in the North-West of Côte d'Ivoire and shares a border in its western part with the Republic of Guinea. It covers an area of $14000 \mathrm{~km}^{2}$ with a population of 193,364, giving a density 13.8 inhabitants per $\mathrm{km}^{2}$ [30]. The climate is tropical sub-humid with annual rainfall varying between 1400 and $1600 \mathrm{~mm}$ per year and annual temperatures ranging between 25.4 and $33{ }^{\circ} \mathrm{C}$. The vegetation is essentially dominated by savannah type vegetation, with trees or shrubs with a grassy tendency. In some places, there are patches of forest and also forest galleries along the water bodies. The district is fed by tributaries of the Sassandra river such as the Bagoué and Tienba rivers. Our surveys were conducted in Gbéléban $\left(09^{\circ} 36^{\prime} \mathrm{N}, 08^{\circ} 08^{\prime} \mathrm{W}\right)$ and Niénésso $\left(09^{\circ} 21^{\prime} \mathrm{N}, 07^{\circ} 36^{\prime} \mathrm{W}\right)$. Gbéléban is bordered at the South by the Gbanala river and has modern housing, a health centre, electricity and water, while Niénésso has no health centre and is bordered at the East by an undeveloped lowland which provides watering for cattle. Most of the local inhabitants are farmers and their staple crops include cereals, tubers, cotton and cashew nuts.

The health district of Ouangolodougou is in the savannah zone in the North of Côte d'Ivoire. It is bordered in the northern part by Burkina Faso and covers an area of $5380 \mathrm{~km}^{2}$, with an estimated population of $260,519 \mathrm{hab}-$ itants, giving a density of 48.4 inhabitants per $\mathrm{km}^{2}$ [30].
The district is characterized by a Sudanese climate with a unimodal rainfall regimen from May to November. The annual rainfall varies from 1000 to $1400 \mathrm{~mm}$, while the mean annual temperature ranges from 21 to $35^{\circ} \mathrm{C}$. The minimum temperatures can drop to $16{ }^{\circ} \mathrm{C}$ due to the Harmattan wind during December and January. The natural vegetation is mainly a mixture of savannah and open forest characterized by trees and shrubs that are approximately $8-15 \mathrm{~m}$ in height. The soil is highly conducive to agriculture and most of the local inhabitants are farmers with staple crops including rice, maize, and cotton. Rice is mainly cultivated during the rainy season in flooded soils. The study area included the villages of Broundougou ( $\left.9^{\circ} 59^{\prime} \mathrm{N} ; 05^{\circ} 09^{\prime} 95^{\prime \prime} \mathrm{W}\right)$ and Satolo $\left(10^{\circ}\right.$ $\left.10^{\prime} \mathrm{N} ; 05^{\circ} 27^{\prime} \mathrm{W}\right)$. Broundougou has a health centre, electricity, water supply and modern houses, whilst Satolo has no modern infrastructure.

Before implementing the study, the local malaria prevalence from 2013 to 2015 recorded in the yearbooks in each district was explored to select the study sites.

\section{Study design}

Entomological surveys were conducted in two villages in each of the four selected health districts of Côte d'Ivoire. The first phase of entomological collections was conducted the between July and December 2016 and a second phase of collections during July-December 2017 to capture seasonal variations in mosquito species diversity and abundance and malaria transmission over years.

\section{Adult mosquito collections}

Adult mosquitoes were sampled using window exit traps (WETs) and pyrethrum knock-down spray collections (PSCs). In each site, 15 WETs were installed on the windows of inhabited houses for two consecutive days per survey. Mosquitoes trapped were collected every morning between $6 \mathrm{a}$.m. and $9 \mathrm{a}$.m. PSCs were performed early each morning from 6 a.m. and 8 a.m., before opening the windows, in ten rooms selected in different dwellings during 2 days per site per district. PSCs were performed in households that were different from those used for WET collections. In case of unavailability or refusal of participants, mosquitoes were collected from neighbouring houses.

\section{Field mosquito processing}

Anopheles mosquitoes were sorted from collected culicines and morphologically identified using morphological identification keys $[31,32]$. The ovaries of the females of Anopheles vectors (An. gambiae s.l., An. funestus s.l., and $A n$. nili) were dissected for parity using the degree of coiling of ovarian tracheoles [33]. All collected Anopheles females were stored individually in Eppendorf tubes 
containing desiccant, labelled according to the study site, point and date of collection, and stored at $-20{ }^{\circ} \mathrm{C}$ for further molecular analysis in the laboratory at the Centre Suisse de Recherches Scientifiques en Côte d'Ivoire in Abidjan, Côte d'Ivoire.

\section{Molecular identification of Anopheles gambiae complex members}

DNA was extracted from the legs of An. gambiae s.l. mosquitoes using the boiling method [34]. Briefly, three legs of each female Anopheles were cut and crushed in $100 \mathrm{~mL}$ of distilled water and boiled at $95^{\circ} \mathrm{C}$ for $10 \mathrm{~min}$. The supernatant was pipetted and transferred into new labelled Eppendorf tubes which were stored at $-20{ }^{\circ} \mathrm{C}$ and used as template for the polymerase chain reaction (PCR).

Anopheles gambiae complex members were identified according to the SINE-PCR molecular method described by Santolamazza et al. [35]. The primer F6.1A with the sequence $5^{\prime}$-TCGCCTTAGACCTTGCGTTA-3' was used to distinguish An. coluzzii and the primer R6.1B with the sequence 5'-CGCTTCAAGAATTCGAGA TAC-3' to distinguish An. gambiae s.s. A LongGene ${ }^{\circledR}$ thermocycler (A200 Gradient Thermal cycler; LongGene Scientific Instruments Co., Ltd Hangzhou, P.R. China) was used with the following programme: $37{ }^{\circ} \mathrm{C}$ for $30 \mathrm{~min}, 94{ }^{\circ} \mathrm{C}$ for $30 \mathrm{~s}$, and $59^{\circ} \mathrm{C}$ for $30 \mathrm{~s} ; 72{ }^{\circ} \mathrm{C}$ for $1 \mathrm{~min}$ repeated 35 times; and a final step at $72{ }^{\circ} \mathrm{C}$ for $10 \mathrm{~min}$ to finish the reaction. An agarose gel was prepared with $2 \%$ agarose in TBE (Tris/borate/EDTA) containing ethidium bromide at $10 \mathrm{mg} / \mathrm{ml}$. The PCR product was loaded onto the agarose gel and allowed to migrate under a voltage of $100 \mathrm{~V}$ for $70 \mathrm{~min}$. The result was visualized with a UV illuminator (TOYOBO Trans Modele TM-20).

\section{Determination of sporozoite rates in Anopheles gambiae}

DNA was extracted from the head and thorax of the adult females of Anopheles vector mosquitoes in each district [36] and screened for Plasmodium DNA using the fast COX-I PCR method described in Echeverry et al. [37]. This is a very sensitive and rapid method which uses a set of primers, COX-IF (5'AGAACGAACGCTTTT AACGCCTG $3^{\prime}$ ) and COX-IR ( $3^{\prime}$ ACTTAATGGTGG ATATAAAGTCCATCCWGT $5^{\prime}$ ), to amplify a polymorphic fragment of the COX-(I) gene using a recombinant DNA polymerase. The thermocycler (TaKaRa PCR Thermal Cycler Dice TP600) program was $94{ }^{\circ} \mathrm{C}$ for $5 \mathrm{~min}$ followed by 40 cycles of $94{ }^{\circ} \mathrm{C}$ for $1 \mathrm{~min}, 62^{\circ} \mathrm{C}$ for $1 \mathrm{~min}$ and $72{ }^{\circ} \mathrm{C}$ for $90 \mathrm{~s}$, and a final elongation step at $72{ }^{\circ} \mathrm{C}$ for $10 \mathrm{~min}$. Five microlitres of the PCR product was visualized on 1\% agarose gel in order to confirm amplification of the expected $\sim 540 \mathrm{bp}$ product (Plasmodium genus positive).

\section{Malaria infection prevalence}

In each health district, data on the malaria prevalence in the local populations were collected from the $\mathrm{MoH}$ statistical yearbooks. The total number of consultations was compared with the number of people examined with malaria from 2016 to 2017.

\section{Data analysis}

Data were double entered in Microsoft Excel 2013 software and transferred to STATA 14 (Stata Corp, College Station, Tx, USA) for analysis. The Kruskal-Wallis $(\mathrm{KW})$ test was used to compare the differences in mosquito densities. The parity rate (PR) was calculated as the number of parous females multiplied by 100 and divided by the total number of females dissected. The $P$. falciparum sporozoite infection rate in each vector species population was calculated by dividing the number of Plasmodium-positive mosquitoes by the total number of mosquitoes tested, and this was expressed as a percentage (\%). The $\chi^{2}$ test was used to compare sporozoite and PR between the collection sites and the health districts. All differences were considered significant at $p<0.05$.

\section{Results}

\section{Mosquito species composition}

Figure 2 shows the species composition of vector species among the anopheline fauna collected in the four health districts of Aboisso, Bloléquin, Odienné and Ouangolodougou. During both year collection periods, a total of 4797 adult Anopheles females were collected using WET and PSCs. Of these, An. gambiae s.l., An. funestus s.l. and An. nili accounted for $99.4 \%$ of Anopheles collected. In Aboisso, Bloléquin, Odienné and Ouangolodougou districts, these three Anopheles species together accounted for $100 \%(\mathrm{n}=281), 99.2 \%(\mathrm{n}=748), 99.3 \%(\mathrm{n}=1309)$

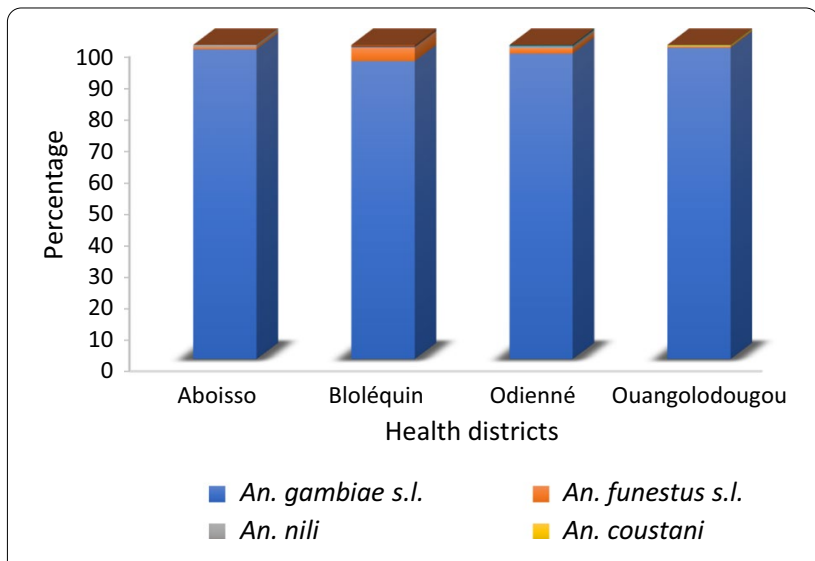

Fig. 2 Species composition of Anopheles mosquitoes collected in four health districts of Côte d'Ivoire from July to December in 2016 and 2017 
and $99.5 \%(\mathrm{n}=2431)$ of anopheline fauna, respectively. Anopheles gambiae s.l. was predominant in all study sites, with particularly higher density in the northern districts of Odienné and Ouangolodougou in savannah area compared to the districts located in the forest area $\left(\mathrm{x}^{2}=22.85 ; \mathrm{df}=4, \mathrm{p}<0.001\right)$. Anopheles funestus s.l. was found in relatively low proportion in three of the four districts: Bloléquin 4.3\% $(\mathrm{n}=754)$; Odienné $1.8 \%(\mathrm{n}=1319)$; Aboisso $0.7 \% \quad(\mathrm{n}=281)$; and Ouangolodougou $0.4 \%$ $(\mathrm{n}=2443)$. Anopheles nili was not found in Ouangolodougou, though the number collected in the others three sites was very low.

\section{Distribution and parity rate of Anopheles gambiae s.l. in the four districts}

Anopheles mosquito density varied significantly from one health district to another ( $\mathrm{KW}=11.03 ; \mathrm{df}=7, p=0.012$ ). The highest density of An. gambiae s.l. was observed in Ouangolodougou [16.7 females/household/day (f/h/d)] and the lowest in Aboisso (1.9 f/h/d). The average densities observed in Aboisso and Bloléquin were similar, being $1.9 \mathrm{f} / \mathrm{h} / \mathrm{d}$ and $2.5 \mathrm{f} / \mathrm{h} / \mathrm{d}$, respectively. In Odienné, the average density was $7.4 \mathrm{f} / \mathrm{h} / \mathrm{d}$. Anopheles gambiae s.l.

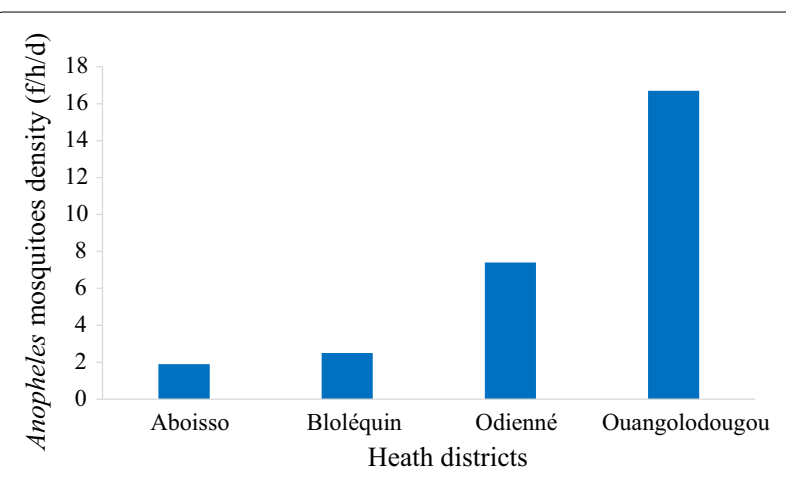

Fig. 3 Anopheles gambiae s.l. density distribution in four health districts of Côte d'Ivoire from July to December in 2016 and 2017 mosquito densities in the four districts were significantly different (KW test $=7.06 ; \mathrm{df}=3 ; p=0.002)$ (Fig. 3).

Table 1 describes the parity rates of An. gambiae s.l. collected in the four health districts. The majority of $A n$. gambiae s.l. dissected were old with an average parity rate of $56.7(\mathrm{n}=4651)$. The highest parity rate was observed in An. gambiae s.l. in Odienné $(69.0 \% ; \mathrm{n}=1258)$, followed by Aboisso (63.8\%; $\mathrm{n}=276)$, Bloléquin $(51.1 \% ; \mathrm{n}=735)$, and Ouangolodougou $(49.2 \% ; n=2382)$. The proportions of parous and nulliparous females of An. gambiae s.l. dissected over the collection period were significantly different in Odienné $\left(\mathrm{x}^{2}=6.46 ; \mathrm{df}=1 ; \mathrm{p}=0.01\right)$, and Ouangolodougou $\left(\mathrm{x}^{2}=15.30 ; \mathrm{df}=1 ; p<0.001\right)$. Significant variation was observed in An. gambiae s.l. parity rates between health districts $(p<0.001)$.

\section{Gambiae complex species distribution}

Figure 4 illustrates the different An. gambiae s.l. species recorded in the study areas within the health districts of Aboisso, Bloléquin, Odienné and Ouangolodougou. All An. gambiae s.l. specimens analysed were either An. gambiae s.s. or An. coluzzii. However, the proportions of each species substantially varied among the health districts.

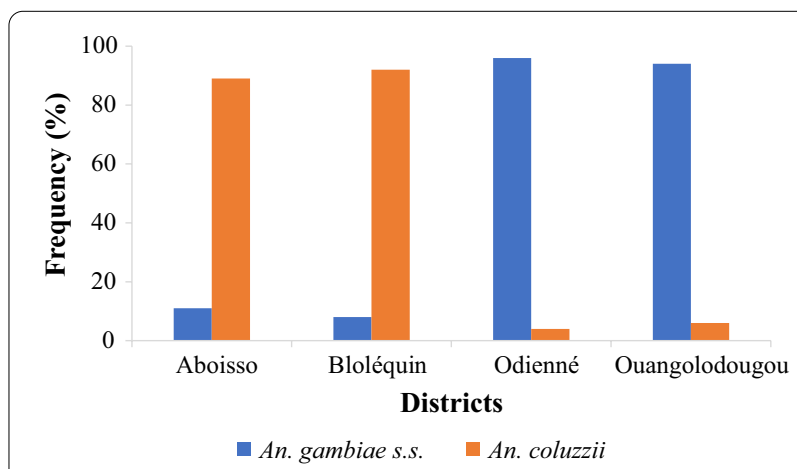

Fig. 4 Distribution of members of Anopheles gambiae complex in four cross-border districts of Côte d'Ivoire from July to December in 2016 and 2017

Table 1 Parity rates of Anopheles gambiae s.l. collected in four cross-border districts of Côte d'Ivoire from July 2016 to December 2017

\begin{tabular}{|c|c|c|c|c|c|}
\hline \multirow[t]{2}{*}{ Districts } & \multirow{2}{*}{$\begin{array}{l}\text { Total dissected } \\
\text { n }\end{array}$} & \multirow{2}{*}{$\begin{array}{l}\text { No. parous } \\
\text { n }\end{array}$} & \multicolumn{2}{|c|}{ Parity rate } & \multirow{2}{*}{$\begin{array}{l}p \text {-value } \\
\text { (Parous/ } \\
\text { nulliparous) }\end{array}$} \\
\hline & & & (\%) & 95\%Cl (\%) & \\
\hline Aboisso & 276 & 176 & 63.8 & {$[57.7-69.4]$} & 0.44 \\
\hline Bloléquin & 735 & 420 & 57.1 & {$[53.4-60.7]$} & 0.78 \\
\hline Odienné & 1258 & 868 & 69.0 & {$[66.3-71.5]$} & $0.01^{*}$ \\
\hline Ouangolodougou & 2382 & 1172 & 49.2 & {$[47.1-51.2]$} & $<0.001^{*}$ \\
\hline Total & 4651 & 2636 & 56.7 & {$[56.1-63.2]$} & 0.31 \\
\hline
\end{tabular}

$n$ number, $\mathrm{Cl}$ confidence interval

*Significant difference, $p=\mathrm{p}$-value 
Anopheles coluzzii was predominant in the health districts of Aboisso and Bloléquin located in the forest zone exhibiting respective proportion of $89.2 \%(n=65)$ and 92.2\% $(\mathrm{n}=115)$ while An. gambiae s.s. exhibited a high frequency in the districts of Odienné $(96.0 \% ; n=100)$ and Ouangolodougou $(94.2 \% ; n=120)$ located in the savannah zone.

\section{Plasmodium infection rate in Anopheles mosquito species}

Table 2 exhibits the $P$. falciparum sporozoite rates detected in the Anopheles species in the four health districts of Aboisso, Bloléquin, Odienné and Ouangolodougou. Only An. gambiae s.l. and An. funestus s.l. was found to be infected with $P$. falciparum sporozoites, while no $P$. falciparum sporozoites was detected in the collected An. nili specimens. In total, 29 mosquitoes were found infected, and the infection rate of malaria vectors ranged from 2 to $10 \%$. Overall $P$. falciparum sporozoite rate in An. gambiae s.l. was 3.1\% $(\mathrm{n}=65, \%$ CI 0.4-10.7) in Aboisso, 7.8\% $(\mathrm{n}=115, \%$ CI 3.6-14.3) in Bloléquin, $11.0 \%(\mathrm{n}=100, \%$ CI $5.6-18.8)$ in Odienné and 3.3\% $(\mathrm{n}=120, \%$ CI $0.9-8.3)$ in Ouangolodougou. There was no significant difference in $P$. falciparum sporozoite rate in An. gambiae s.l. between the health districts $\left(\chi^{2}=7.33\right.$; $\mathrm{df}=3, \mathrm{p}=0.065)$. In An. funestus s.l., the P. falciparum sporozoite rate was $6.2 \%(2 / 32, \%$ CI $0.7-20.8)$ in Bloléquin and 8.7\% (2/23, \% CI 1.1-28.0) in Odienné, but no $P$. falciparum sporozoites was detected in this species of Aboisso (0/2) and Ouangolodougou (0/11).

\section{Malaria prevalence among local human populations}

Figure 5 indicates the malaria prevalence rate among the population of the four health districts from 2016 to 2017. The prevalence rate was high in Odienné (39.7\%; $\mathrm{n}=45,376)$ and Bloléquin $(37.6 \% ; \mathrm{n}=150,205)$ health districts, compared to Ouangolodougou (18.3\%; $\mathrm{n}=131,629)$, and Aboisso (19.7\%; $\mathrm{n}=364,585)$.

Table 2 Plasmodium falciparum sporozoite rates in Anopheles mosquito species collected in four cross-border districts of Côte d'Ivoire from July 2016 to December 2017

\begin{tabular}{|c|c|c|c|c|c|c|c|c|}
\hline \multirow[t]{2}{*}{ Species } & \multicolumn{2}{|l|}{ Aboisso } & \multicolumn{2}{|l|}{ Bloléquin } & \multicolumn{2}{|l|}{ Odienné } & \multicolumn{2}{|c|}{ Ouangolodougou } \\
\hline & $\begin{array}{l}\text { No. tested } \\
\text { (infected) }\end{array}$ & $\begin{array}{l}\text { SR (\%) } \\
\mathrm{Cl}(95 \%)\end{array}$ & $\begin{array}{l}\text { No. tested } \\
\text { (infected) }\end{array}$ & $\begin{array}{l}\text { SR (\%) } \\
\mathrm{Cl}(95 \%)\end{array}$ & $\begin{array}{l}\text { No. tested } \\
\text { (infected) }\end{array}$ & $\begin{array}{l}\text { SR (\%) } \\
\mathrm{Cl}(95 \%)\end{array}$ & $\begin{array}{l}\text { No. tested } \\
\text { (infected) }\end{array}$ & $\begin{array}{l}\text { SR (\%) } \\
\mathrm{Cl}(95 \%)\end{array}$ \\
\hline An. gambiaes.l & $65(2)$ & $3.1[0.4-10.7]$ & $115(9)$ & 7.8 [3.6-14.3] & $100(11)$ & $11.0[5.6-18.8]$ & $120(3)$ & $2.5[0.5-7.1]$ \\
\hline An.funestus s.l & $2(0)$ & $0.0[0.0-84.2]$ & $32(2)$ & $6.2[0.7-20.8]$ & $23(2)$ & $8.7[1.1-28.0]$ & $11(0)$ & $0.0[0.0-28.5]$ \\
\hline An. nili & $2(0)$ & $0.0[0.0-84.2]$ & $1(0)$ & $0.0[0.0-97.5]$ & $4(0)$ & $0.0[0.0-60.2]$ & $0.0(0)$ & $0.0[0-0]$ \\
\hline Total & $69(2)$ & $2.9[0.3-10.1]$ & $148(11)$ & 7.4 [3.8-12.9] & $127(13)$ & $10.2[5.6-16.9]$ & $131(3)$ & $2.3[0.5-6.5]$ \\
\hline
\end{tabular}

No. tested number of mosquitoes tested, $S R$ sporozoite rate, \% percentage, $C l$ confidence interval

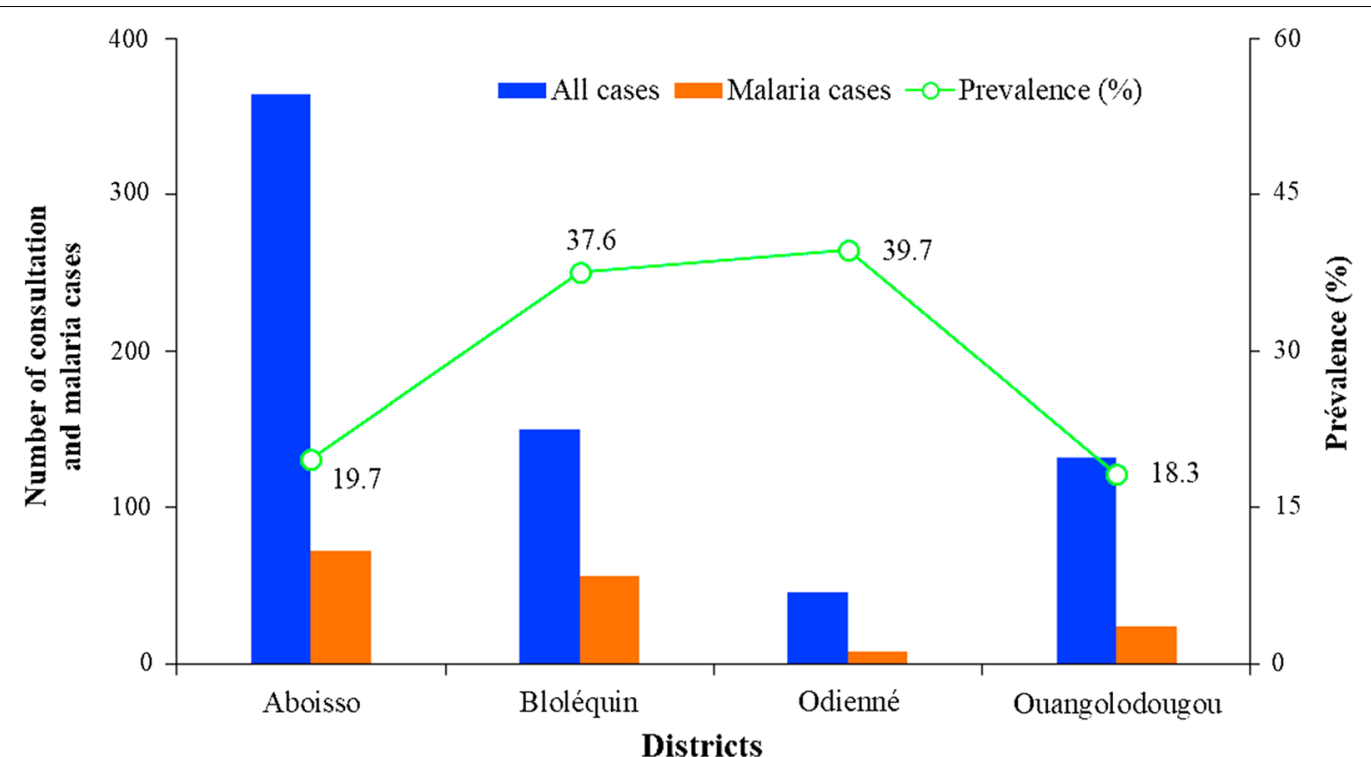

Fig. 5 Prevalence of malaria among the population of the four health districts of Côte d'Ivoire from 2016 to 2017 


\section{Discussion}

Malaria is still a leading cause of death and poverty in the majority of the countries in sub-Saharan Africa due to country vectors specificity and even differences within ecological zones of a country implying targeted monitoring to better understand and support vector control decision-making. This study assessed Anopheles mosquito vectors and malaria transmission in district health facilities at the borders of Côte d'Ivoire, coupled with the malaria incidence during the second semester of both 2016 and 2017 [38]. In this study, the relative diversity and abundance of Anopheles mosquitoes in four districts located at the borders of Côte d'Ivoire has been highlighted and assessed their implications in malaria transmission to local communities. The results have shown that $A n$. gambiae s.l. was most the abundant vector of malaria in the four districts. Moreover, Plasmodium sporozoite infection rate in An. gambiae s.l. and An. funestus s.l. was higher in Odienné (11.0\% and $8.27 \%$, respectively) and Bloléquin ( $7.8 \%$ and $6.2 \%$, respectively), compared with Aboisso (3.1\% and 0\%, respectively) and Ouangolodougou $(2.5 \%$ and $0 \%$, respectively). Similarly, malaria prevalence rate among people in Odienné (39.7\%) and Bloléquin (37.6\%) health districts was higher compared with that in Ouangolodougou (18.3\%), and Aboisso (19.7\%) health districts.

A diversity of Anopheles mosquito species including seven Anopheles species was recorded, among which three (An. gambiae s.l., An. funestus s.l. and An. nili) have previously been incriminated in malaria transmission in Côte d'Ivoire [22, 39]. Moreover, An. gambiae s.l. was the predominant species in all study sites, with particularly higher abundance in the northern health districts of Ouangolodougou and Odienné located in savannah zones compared with the districts of Aboisso and Bloléquin situated in forest zones. The high diversity and variation in the relative abundance of Anopheles mosquito species might result from a combination of ecological and climatic factors favouring the larval development of some species. Indeed, permanent water sources, puddles and small dams are probably abundant in these areas $[40,41]$.

The diversity and variation in Anopheles mosquito species composition are mostly related to human activities (e.g., rice farming, vegetable crops) [42, 43]. Odienné and Ouangolodougou are rural districts in which several crops are cultivated including rice, maize, yam, vegetable crops, cashew nuts and cotton. Rice paddies and vegetable crops were strongly associated with high densities of malaria vectors [44, 45]. In addition, An. gambiae s.l. exhibited high parity rates in all districts, thus suggesting that a significant proportion of the local vector populations that have sufficient lifespan allowing for the completion of Plasmodium parasite lifecycle and transmission to humans. Similar findings have previously been reported in Côte d'Ivoire [46, 47].

This study showed that An. coluzzii was the predominant species in forest area, whilst An. gambiae s.s. was the dominant species in savannah. The relative abundance of these two species is associated with specific and characteristic breeding sites as previously reported in Côte d'Ivoire [40, 48]. The abundance of $A n$. coluzzii in samples from forest areas could be related to the type of breeding sites and the climatic conditions in these study sites $[49,50]$. Several studies carried out in Côte d'Ivoire have shown a predominance of $A n$. coluzzii in forest area especially in the western [22] and south-eastern [51] parts. The highest abundance of An. gambiae s.s. was observed in the savannah area where relatively abundant precipitation provides more favorable humidity and temperature conditions $[52,53]$. The predominance of $A n$. gambiae s.s. in savannah zones has been observed by Touré et al. [54] and Tia et al. [48], suggesting that environmental conditions in savannah zones are unfavourable for the reproduction and the survival of An. coluzzii.

Understanding malaria transmission at the local level is essential for the development and implementation of effective vector control strategies. Thus, to identify potential vector species of malaria in our various study sites, individual females of An. gambiae s.l. were tested using molecular PCR for the presence of $P$. falciparum sporozoites. The finding showed that only two species were involved in malaria transmission across the four health districts, with $A n$. gambiae s.l. being the main malaria vector in all districts. In addition, $A n$. gambiae s.l. and $A n$. funestus s.l. were efficient vectors of $P$. falciparum in these two cross-border districts. This observation is consistent with findings from previous studies showing that the high capacity of malaria vectors ensures high transmission in an ecological area is intimately related with environmental conditions [21, 22]. Although infection rates were almost similar between study sites, the intensity of transmission was very heterogeneous. Malaria transmission is lower in Aboisso and Ouangolodougou health districts. In contrast, it remains relatively high in Bloléquin and Odienné districts where two additional Anopheles vectors are involved in malaria transmission. This high transmission of malaria could possibly be due to the high infection rate of malaria vectors and the non-respect of vector control measures in these districts where control strategy is based mainly on the distribution of distribution of LLINs. In addition, the presence of several vectors in the same area could significantly increase the risk of malaria transmission. This study suggests that malaria vector control interventions should be strengthened in Bloléquin and Odienné 
in order to reduce or eliminate the burden of malaria in these districts.

The low prevalence of malaria observed $(<20 \%)$ in the health districts of Aboisso and Ouangolodougou suggests that both districts are in areas of moderate transmission [55]. In contrast, high prevalence rates of $P$. falciparum infections (ranging from 37.6 to 39.7\%) in Bloléquin and Odienné may imply that these districts are areas of high malaria transmission. This variation of Plasmodium transmission from one health district to another may be related to climatic conditions. Several previous studies have shown that Plasmodium infections are influenced by environmental factors such as temperature, rainfall, humidity and altitude [56, 57]. These factors directly or indirectly influence the development and appearance of Anopheles mosquitoes and, thus, the geographical distribution of the malaria infection and disease. The heterogeneity of malaria transmission observed in the present study is consistent with previous studies [27, 39]. This may also be the effect of differences in intervention strategies coordinated by the National Malaria Control Programme (NMCP), especially mass distribution of LLINs to vulnerable population and the use of ACT for the early treatment of malaria cases.

The country experienced already four campaigns of LLINs distribution and malaria transmission remains high and heterogeneous across cross-border health districts of Côte d'Ivoire with the presence of several vector species: An. funestus s.l., An. nili and An. gambiae s.l. The latter is the most species encountered. The study showed a high diversity and abundance of Anopheles mosquitoes, which could contribute to malaria transmission persistence over time. Moreover, high sporozoite infection and parity rates were recorded in all four heath districts and highlighted the high transmission of malaria within local populations. Currently, the vector control strategy of NMCP of Côte d'Ivoire is based on LLIN distribution. Recently in August 2020, the President Malaria Initiative (PMI) through the $\mathrm{MoH}$ implemented IRS in pilot site (Sakassou), in order to strengthen LLINs effects that have already proven effective in individual and community protection against malaria. $[58,59]$. However, in the recent past, pyrethroids were the single insecticide class used for impregnation of LLINs, owing to their rapid action, excito-repellent effects, effectiveness at low doses and low toxicity to humans [60]. Unfortunately, pyrethroid resistance in malaria vectors has emerged and spread rapidly in Côte d'Ivoire [61] and several parts of Africa [62-64]. Therefore, efforts should be made to evaluate the effectiveness of insecticide-treated LLINs with different modes of action to which there is no crossresistance and to evaluate promising tools to be used in combination with LLINs in highly endemic areas. Since mosquito capture has been done indoors, it is important to rapidly roll out the implementation of IRS nationally in highly endemic districts using next generation formulations, which has already proven its effectiveness in combination with LLIN [65].

\section{Conclusion}

The specific diversity and abundance of anopheline vectors were high in the cross-border health districts of Côte d'Ivoire. Plasmodium sporozoite infection rates were also high, leading to continued and high transmission of malaria in local populations. Anopheles gambiae s.l. was the main malaria vector, with An. funestus playing a secondary vector role in the health districts of Bloléquin and Odienné. Malaria transmission remained high in the health districts of Odienné and Bloléquin where two additional vectors were involved, compared to the districts of Aboisso and Ouangolodougou. Anopheles coluzzii was most common in forest areas while $A n$. gambiae s.s. predominated in the savannah areas of Côte d'Ivoire. Therefore, it is necessary to regularly monitor the bionomics of local Anopheles vector species and follow up possible change in malaria transmission dynamics to strengthen national vector control strategies taking into account the cross-border regions of Côte d'Ivoire. These observations may not only inform future research perspectives but should hopefully also guide future decision-making on malaria control strategies, especially in these cross-border areas of Côte d'Ivoire.

\section{Abbreviations}

ACT: Artemisinin-based combination therapy; COX-I: Cytochrome oxidase I; CSRS: Centre Suisse de Recherches Scientifiques; DNA: Deoxyribonucleic acid; EDTA: Ethylenediaminetetraacetic acid; IRS: Indoor residual spraying; KW: Kruskal-Wallis; LLINs: Long-lasting insecticidal nets; MoH: Ministry of Health; NMCP: National Malaria Control Programme; PCR: Polymerase chain reaction; PR: Parity rate; PSC: Pyrethrum spray collection; SINE-PCR: Short interspersed nuclear element-based polymerase chain reaction; TBE: Tris borate EDTA; UV: Ultraviolet; WET: Window exit traps.

\section{Acknowledgements}

The authors are grateful to health authorities, local authorities, and the mosquito collection teams to the different districts.

\section{Authors' contributions}

FNY, JBZZ and BGK designed surveys. FNY and JBZZ carried out the surveys. FNY, MO and DKdS conducted PCR assays. AFO analysed data. FNY drafted the manuscript. JBZZ, SG, AFO and BGK critically revised the manuscript. All authors read and approved the final manuscript.

\section{Funding}

This project was funded by the core funds of Centre Suisse de Recherches Scientifiques in Cote d'Ivoire through special Seed Money funds.

Availability of data and materials

All data generated or analysed during this study are included in this article and are available from the corresponding author. 


\section{Declarations}

\section{Ethics approval and consent to participate}

Ethical clearance for this study was obtained from the National Ethics Review Committee of Côte d'Ivoire (001//MSHP/CNER-kp). This study also received an approval from the health authorities of each district. In each study area, permission to work was granted by the community leaders or chiefs of villages. Community members and house owners get clear information on objectives, procedures, potential risks of harm and benefits related to the study and then oral informed consent and permission to conduct activities was provided. Participation in mosquito collection was strictly based on volunteering and all collectors were trained on the specific mosquito collection methods prior to initiation of the study.

\section{Consent for publication}

Not applicable.

\section{Competing interests}

The authors declare that they have no conflict of interest.

\section{Author details}

'Unité de Formation et de Recherche Sciences de la Nature, Université Nangui Abrogoua, Abidjan, Côte d'Ivoire. ${ }^{2}$ Centre Suisse de Recherches Scientifiques en Côte d'Ivoire, Abidjan, Côte d'Ivoire. ${ }^{3}$ Centre d'Entomologie Médicale et Vétérinaire, Université Alassane Ouattara, Bouaké, Côte d'Ivoire. ${ }^{4}$ Innovative Vector Control Consortium (IVCC), Pembroke Place, Liverpool L3 5QA, UK. ${ }^{5}$ Department of Parasitology, Noguchi Memorial Institute for Medical Research, University of Ghana, Legon, Accra, Ghana. ${ }^{6}$ European \& Developing Countries Clinical Trials Partnership, Cape Town, South Africa.

Received: 12 September 2020 Accepted: 1 October 2021 Published online: 18 October 2021

\section{References}

1. WHO. World malaria report 2019. Geneva, World Health Organization. 2019. https://www.who.int/publications/i/item/world-malaria-report2019. Accessed 28 Aug 2020.

2. WHO. World malaria report 2020. Geneva, World Health Organization, 2020. https://www.who.int/teams/global-malaria-/programme/reports/ world-malaria-report-2020. Accessed 8 Apr 2021

3. CDC. Centers for disease control and prevention in Côte d'Ivoire. 2020 https://www.cdc.gov/globalhealth/countries/cote-d-ivoire/pdf/Cote-DIvoire_Factsheet.pdf. Accessed 28 Aug 2020.

4. WHO. World malaria report 2016. Geneva, World Health Organization. 2016. http://apps.who.int/iris/bitstream/10665/252038/1/9789241511 711-eng.pdf?ua=1. Accessed 28 Aug 2020.

5. Antonio-Nkondjio C, Ndo C, Njiokou F, Bigoga JD, Awono-Ambene P, Etang J, et al. Review of malaria situation in Cameroon: technical viewpoint on challenges and prospects for disease elimination. Parasit Vectors. 2019;12:501.

6. Hoo R, Zhu L, Amaladoss A, Mok S, Natalang O, Lapp SA, et al. Integrated analysis of the Plasmodium species transcriptome. EBioMedicine. 2016:7:255-66

7. Dayananda K, Achur R, Gowda Dc. Epidemiology, drug resistance, and pathophysiology of Plasmodium vivax malaria. J Vector Borne Dis. 2018;55:1-8.

8. Otto TD, Gilabert A, Crellen T, Böhme U, Arnathau C, Sanders M, et al. Genomes of all known members of a Plasmodium subgenus reveal paths to virulent human malaria. Nat Microbiol. 2018;3:687-97.

9. Wiebe A, Longbottom J, Gleave K, Shearer FM, Sinka ME, Massey NC, et al. Geographical distributions of African malaria vector sibling species and evidence for insecticide resistance. Malar J. 2017;16:85.

10. Coetzee M, Hunt RH, Wilkerson R, Della Torre A, Coulibaly MB, Besansky NJ. Anopheles coluzzii and Anopheles amharicus, new members of the Anopheles gambiae complex. Zootaxa. 2013;3619:246-74.

11. Sinka ME, Golding N, Massey NC, Wiebe A, Huang Z, Hay SI, et al. Modelling the relative abundance of the primary African vectors of malaria before and after the implementation of indoor, insecticide-based vector control. Malar J. 2016;15:142.

12. Ossè RA, Tokponnon F, Padonou GG, Sidick A, Aïkpon R, Fassinou A, et al. Involvement of Anopheles nili in Plasmodium falciparum transmission in North Benin. Malar J. 2019:18:152.

13. WHO. World malaria report 2018. Geneva, World Health Organization. 2018. https:/apps.who.int/iris/bitstream/handle/10665/275867/97892 41565653-eng.pdf. Accessed 16 July 2021.

14. Ong'wen F, Onyango PO, Bukhari T. Direct and indirect effects of predation and parasitism on the Anopheles gambiae mosquito. Parasit Vectors. 2020;13:43.

15. Kudom AA. Larval ecology of Anopheles coluzzii in Cape Coast, Ghana: water quality, nature of habitat and implication for larval control. Malar J. 2015:14:447.

16. Getachew D, Balkew M, Tekie H. Anopheles larval species composition and characterization of breeding habitats in two localities in the Ghibe River Basin, southwestern Ethiopia. Malar J. 2020;19:65

17. Mbida AM, Etang J, Ntonga PA, Eboumbou Moukoko C, Awono-Ambene P, Tagne D, et al. Nouvel aperçu sur l'écologie larvaire d'Anopheles coluzzii Coetzee et Wilkerson, 2013 dans l'estuaire du Wouri, Littoral-Cameroun. Bull Soc de Pathol Exot. 2017;110:92-101.

18. Ossè RA, Bangana SB, Aïkpon R, Kintonou J, Sagbohan H, Sidick A, et al. Adaptation of Anopheles coluzzii larvae to polluted breeding Sites in Cotonou: a strengthening in urban malaria transmission in Benin. Vector Biol J. 2019;4:1.

19. Mourou J-R, Coffinet T, Jarjaval F, Cotteaux C, Pradines E, Godefroy L, et al. Malaria transmission in Libreville: results of a one-year survey. Malar J. 2012;11:40

20. Killen GF. Characterizing, controlling and eliminating residual malaria transmission. Malar J. 2014;13:330.

21. Deressa W, Loha E, Balkew M, Hailu A, Gari T, Kenea O, et al. Combining long-lasting insecticidal nets and indoor residual spraying for malaria prevention in Ethiopia: study protocol for a cluster randomized controlled trial. Trials. 2016;17:20

22. Koffi AA, Alou LPA, Kabran J-PK, N'Guessan R, Pennetier C. Re-visiting insecticide resistance status in Anopheles gambiae from Côte d'Ivoire: a nation-wide informative survey. PLoS ONE. 2013;8: e82387.

23. Zogo B, Soma DD, Tchiekoi BN, Somé A, Ahoua-Alou LP, Koffi AA, et al. Anopheles bionomics, insecticide resistance mechanisms, and malaria transmission in the Korhogo area, northern Côte d'Ivoire: a pre-intervention study. Parasite. 2019;26:40.

24. Adja AM, N'Goran EK, Koudou BG, Dia I, Kengne P, Fontenille D, et al. Contribution of Anopheles funestus, An. gambiae and An. nili (Diptera: Culicidae) to the perennial malaria transmission in the southern and western forest areas of Côte d'Ivoire. Ann Trop Med Parasitol. 2011;105:13-24.

25. Gbalegba TE, M'Bra NGC, Kaba KR, Boby A, Koné OAM, Chouaibou M, et al Étude du niveau de production larvaire d'Anopheles gambiae s.l. (Diptera: Culicidae) dans différents types de gîtes à Oussou-yaokro au CentreOuest et à Korhogo, au Nord (Côte d'Ivoire). J App Biosci. 2016;105:10170.

26. Edi CA, Koudou BG, Bellai L, Adja AM, Chouaibou M, Bonfoh B, et al. Longterm trends in Anopheles gambiae insecticide resistance in Côte d'Ivoire. Parasit Vectors. 2014;7:500.

27. Raso G, Schur N, Utzinger J, Koudou BG, Tchicaya ES, Rohner F, et al. Mapping malaria risk among children in Côte d'Ivoire using Bayesian geo-statistical models. Malar J. 2012;11:160.

28. Fofana D, Koné AB, Konan YL, Konan KL, Doannio JMC, N'goran EK. Transmission des plasmodies humaines dans les villages de N'gatty et d'Allaba en milieu lagunaire de Côte d'Ivoire. Cahiers de Santé. 2010;20:73-9.

29. Texier G, Machault V, Barragti M, Boutin JP, Rogier C. Environmental determinant of malaria cases among travellers. Malar J. 2013;12:87.

30. RGPH. Recensement Général de la Population et de l'Habitat 2014. Statistiques en régions_Institut Nationale de la Statistique. http://www. ins.ci/n/index.php?option=com_content\&view=article\&id=94\&ltemid= 93. Accessed 8 Apr 2021.

31. Harbach R. The mosquitoes of the subgenus Culex in the Southwester Asia and Egypt (Diptera: Culicidae). Contrib Amer Ent Inst. 1988:24:240.

32. Gillies M, Coetzee M. A supplement to the Anophelinae of Africa south of the Sahara (Afrotropical region). Publ S Afr Inst Med Res. 1987;55:1-43.

33. Detinova TS. Méthodes à appliquer pour classer par groupes d'âges les diptères présentant une importance médicale. Notamment certains vecteurs du paludisme. WHO Monog Ser. 1963;47:220. 
34. de Souza DK, Koudou BG, Bolay FK, Boakye DA, Bockarie MJ. Filling the gap 115 years after Ronald Ross: the distribution of the Anopheles coluzzii and Anopheles gambiae s.s from Freetown and Monrovia, West Africa. PLOS ONE. 2013;8: e64939.

35. Santolamazza F, Mancini E, Simard F, Qi Y, Tu Z, della Torre A. . Insertion polymorphisms of SINE200 retrotransposons within speciation islands of Anopheles gambiae molecular forms. Malar J. 2008;7:163.

36. Obenauer PJ, Abdel-Dayem MS, Stoops CA, Villinski JT, Tageldin R, Fahmy NT, et al. Field responses of Anopheles gambiae complex (Diptera: Culicidae) in Liberia using yeast-generated carbon dioxide and synthetic lure-baited light traps. J Med Entomol. 2013;50:863-70.

37. Echeverry DF, Deason NA, Makuru V, Davidson J, Xiao H, Niedbalski J, et al. Fast and robust single PCR for Plasmodium sporozoite detection in mosquitoes using the cytochrome oxidase I gene. Malar J. 2017;16:230.

38. Fontenille D, Cohuet A, Awono-Ambene PH, Antonio-Nkondjio C, Wondji C, Kengne P, et al. Systematics and biology of Anopheles vectors of Plasmodium in Africa, recent data. Med Trop. 2003;63:247-53 (in French).

39. Assouho KF, Adja AM, Guindo-Coulibaly N, Tia E, Kouadio AMN, Zoh DD, et al. Vectorial transmission of malaria in major districts of Côte d'Ivoire. J Med Entomol. 2020;57:908-14.

40. Coetzee M, Craig M, le Sueur D. Distribution of African malaria mosquitoes belonging to the Anopheles gambiae complex. Parasitol Today. 2000;16:74-7.

41. Betsi AN, Tchicaya ES, Koudou BG. Forte prolifération de larves d'An. gambiae et An. funestus en milieux rizicoles irrigués et non irrigués dans la région forestière ouest de la Côte-d'Ivoire. Bull Soc Pathol Exot. 2012;105:220-9.

42. Ouldabdallahi Moukah M, Ba O, Ba H, Ould-Khairy ML, Faye O, Bogreau $\mathrm{H}$, et al. Malaria in three epidemiological strata in Mauritania. Malar J. 2016;15:204.

43. Musiime AK, Smith DL, Kilama M, Rek J, Arinaitwe E, Nankabirwa Jl, et al, Impact of vector control interventions on malaria transmission intensity, outdoor vector biting rates and Anopheles mosquito species composition in Tororo, Uganda. Malar J. 2019;18:445.

44. Fodjo BK, Koudou BG, Tia E, Saric J, N'dri PB, Zoh MG. Insecticides resistance status of An. gambiae in areas of varying agrochemical use in Côte d'Ivoire. BioMed Res Int. 2018;2018:1-9.

45. Koudou BG, Adja AM, Matthys B, Doumbia M, Cissé G, Koné M, et al. Pratiques agricoles et transmission du paludisme dans deux zones éco-épidémiologiques au centre de la Côte d'Ivoire. Bull Soc Pathol Exot. 2007;100:124-6.

46. Koudou BG, Tano Y, Doumbia M, Nsanzabana C, Cisse G, Girardin O, et al. Malaria transmission dynamics in central Côte d'Ivoire: the influence of changing patterns of irrigated rice agriculture. Med Vet Entomol. 2005;19:27-37.

47. Diakité NR, Guindo-Coulibaly N, Adja AM, Ouattara M, Coulibaly JT, Utzinger J, et al. Spatial and temporal variation of malaria entomological parameters at the onset of a hydro-agricultural development in central Côte d'Ivoire. Malar J. 2015;14:340.

48. Tia E, Chouaibou M, Gblégba NGC, Boby OAM, Koné M, Kadjo KA. Distribution des espèces et la fréquence du gène $k d r$ chez les populations de Anopheles gambiae s.s. et de Anopheles coluzzii dans cinq sites agricoles de la Côte d'ivoire. Bull Soc Path Exot. 2017;110:130-4.

49. Kamdem C, Fossog BT, Simard F, Etouna J, Ndo C, Kengne P, et al. Anthropogenic habitat disturbance and ecological divergence between incipient species of the malaria mosquito Anopheles gambiae. PLoS ONE. 2012;7: e39453.

50. Etang J, Mbida Mbida A, Ntonga Akono P, Binyang J, Eboumbou Moukoko CE, Lehman LG, et al. Anopheles coluzzii larval habitat and insecticide resistance in the island area of Manoka, Cameroon. BMC Infect Dis. 2016;16:217.
51. Alou LPA, Koffi AA, Adja MA, Assi SB, Kouassi PK, N'Guessan R. Status of pyrethroid resistance in Anopheles gambiae s.s M form prior to the scaling up of long-lasting insecticidal nets (LLINs) in Adzopé, Eastern Côte d'Ivoire. Parasit Vectors. 2012;5:289.

52. Depinay J-MO, Mbogo CM, Killeen G, Knols B, Beier J, Carlson J, et al. A simulation model of African Anopheles ecology and population dynamics for the analysis of malaria transmission. Malar J. 2004;3:29.

53. Coulibaly B, Koné R, Barry MS, Emerson B, Coulibaly MB, Niare $O$, et al. Malaria vector populations across ecological zones in Guinea Conakry and Mali, West Africa. Malar J. 2016;15:191.

54. Touré $M$, Carnevale $P$, Chandre F. Impact retardé des moustiquaires imprégnées de lambdacyhalothrine sur la fréquence de la mutation kdr chez Anopheles gambiae s.s. (Diptera: Culicidae) au nord de la Côte d'Ivoire. Bull Soc Path Exot. 2012;105:305-10

55. Rougier C, Henry MC, Trape JF. Evaluation épidémiologique du paludisme en zone d'endémie. Med Trop. 2009;69:123-42.

56. Stresman GH. Beyond temperature and precipitation: ecological risk factors that modify malaria transmission. Acta Trop. 2010;116:167-72.

57. Lefevre T, Ohm J, Dabiré KR, Cohuet A, Choisy M, Thomas MB, et al. Transmission traits of malaria parasites within the mosquito: genetic variation, phenotypic plasticity, and consequences for control. Evol Appl. 2017;11:456-69.

58. Damien GB, Djènontin A, Chaffa E, Yamadjako S, Drame PM, Ndille EE, et al. Effectiveness of insecticidal nets on uncomplicated clinical malaria: a case-control study for operational evaluation. Malar J. 2016;15:102.

59. Hounkonnou $C$, Djènontin $A$, Egbinola $S$, Houngbegnon $P$, Bouraima $A$, Soares $C$, et al. Impact of the use and efficacy of long-lasting insecticidal net on malaria infection during the first trimester of pregnancy-a pre-conceptional cohort study in southern Benin. BMC Public Health. 2018;18:683.

60. Sovi A, Govoétchan R, Ossé R, Koukpo CZ, Salako AS, Syme T, et al. Resistance status of Anopheles gambiae s.l. to insecticides following the 2011 mass distribution campaign of long-lasting insecticidal nets (LLINs) in the Plateau Department, south-eastern Benin. Malar J. 2020;19:26.

61. Camara S, Koffi AA, Alou LPA, Koffi K, Kabran J-PK, Koné A, et al. Mapping insecticide resistance in Anopheles gambiae (s.l.) from Côte d'Ivoire. Parasit Vectors. 2018;11:19.

62. Aïkpon RY, Padonou G, Dagnon F, Ossè R, Ogouyemi Hounto A, Tokponon $F$, et al. Upsurge of malaria transmission after indoor residual spraying withdrawal in Atacora region in Benin, West Africa. Malar J. 2020;19:3.

63. Chukwuekezie O, Nwosu E, Nwangwu U, Dogunro F, Onwude C, Agashi $\mathrm{N}$, et al. Resistance status of Anopheles gambiae (s.l.) to four commonly used insecticides for malaria vector control in South-East Nigeria. Parasit Vectors. 2020;13:152.

64. Wat'senga F, Agossa F, Manzambi EZ, Illombe G, Mapangulu T, Muyembe $\mathrm{T}$, et al. Intensity of pyrethroid resistance in Anopheles gambiae before and after a mass distribution of insecticide-treated nets in Kinshasa and in 11 provinces of the Democratic Republic of Congo. Malar J. 2020;19:169.

65. Oxborough RM, Seyoum A, Yihdego Y, Dabire R, Gnanguenon V, Wat'senga F, et al. Susceptibility testing of Anopheles malaria vectors with the neonicotinoid insecticide clothianidin; results from 16 African countries, in preparation for indoor residual spraying with new insecticide formulations. Malar J. 2019;18:264.

\section{Publisher's Note}

Springer Nature remains neutral with regard to jurisdictional claims in published maps and institutional affiliations. 